\title{
Alterations in Gas Exchange and Oxidative Metabolism in Rice Leaves Infected by Pyricularia oryzae are Attenuated by Silicon
}

\author{
Gisele Pereira Domiciano, Isaías Severino Cacique, Cecília Chagas Freitas, Marta Cristina Corsi Filippi, \\ Fábio Murilo DaMatta, Francisco Xavier Ribeiro do Vale, and Fabrício Ávila Rodrigues
}

First, second, third, sixth, and seventh authors: Universidade Federal de Viçosa (UFV), Departamento de Fitopatologia, Laboratório da Interação Planta-Patógeno, Viçosa, MG, 36570-900, Brazil; fourth author: EMBRAPA—National Research Center for Rice and Beans, Plant Pathology Section, Santo Antônio de Goiás, GO, 75375-000, Brazil; fifth author: UFV, Departamento de Biologia Vegetal, Brazil.

Accepted for publication 13 January 2015.

\begin{abstract}
Domiciano, G. P., Cacique, I. S., Freitas, C. C., Filippi, M. C. C., DaMatta, F. M., Vale, F. X. R., and Rodrigues, F. A. 2015. Alterations in gas exchange and oxidative metabolism in rice leaves infected by Pyricularia oryzae are attenuated by silicon. Phytopathology 105:738-747.

Rice blast, caused by Pyricularia oryzae, is the most important disease in rice worldwide. This study investigated the effects of silicon $(\mathrm{Si})$ on the photosynthetic gas exchange parameters (net $\mathrm{CO}_{2}$ assimilation rate $[A]$, stomatal conductance to water vapor $\left[g_{\mathrm{s}}\right]$, internal-to-ambient $\mathrm{CO}_{2}$ concentration ratio $\left[C_{\mathrm{i}} / C_{\mathrm{a}}\right]$, and transpiration rate $\left.[E]\right)$; chlorophyll fluorescence $a\left(\mathrm{Chl}_{a}\right)$ parameters (maximum photochemical efficiency of photosystem II $\left[F_{\mathrm{v}} / F_{\mathrm{m}}\right]$, photochemical $\left[q_{\mathrm{P}}\right]$ and nonphotochemical [NPQ] quenching coefficients, and electron transport rate [ETR]); concentrations of pigments, malondialdehyde (MDA), and hydrogen peroxide $\left(\mathrm{H}_{2} \mathrm{O}_{2}\right)$; and activities of superoxide dismutase (SOD), catalase (CAT), ascorbate peroxidase (APX), glutathione reductase (GR), and lypoxigenase (LOX) in rice leaves. Rice

with higher foliar Si concentration. The values of $A, g_{\mathrm{s}}$ and $E$ were generally higher for the $+\mathrm{Si}$ plants in comparison with the $-\mathrm{Si}$ plants upon $P$. oryzae infection. The $F_{\mathrm{v}} / F_{\mathrm{m}}, q_{\mathrm{p}}, \mathrm{NPQ}$, and ETR were greater for the + Si plants relative to the $-\mathrm{Si}$ plants at 108 and $132 \mathrm{~h}$ after inoculation (hai). The values for $q_{\mathrm{p}}$ and ETR were significantly higher for the $-\mathrm{Si}$ plants in comparison with the $+\mathrm{Si}$ plants at 36 hai, and the NPQ was significantly higher for the $-\mathrm{Si}$ plants in comparison with the $+\mathrm{Si}$ plants at 0 and 36 hai. The concentrations of $\mathrm{Chl}_{a}, \mathrm{Chl}_{b}, \mathrm{Chl}_{a+b}$, and carotenoids were significantly greater in the $+\mathrm{Si}$ plants relative to the $-\mathrm{Si}$ plants. For the $-\mathrm{Si}$ plants, the MDA and $\mathrm{H}_{2} \mathrm{O}_{2}$ concentrations were significantly higher than those in the $+\mathrm{Si}$ plants. The LOX activity was significantly higher in the $+\mathrm{Si}$ plants than in the - Si plants. The SOD and GR activities were significantly higher for the $-\mathrm{Si}$ plants than in the $+\mathrm{Si}$ plants. The CAT and APX activities were significantly higher in the $+\mathrm{Si}$ plants than in the $-\mathrm{Si}$ plants. The supply of $\mathrm{Si}$ contributed to a decrease in blast severity, improved the gas exchange performance, and caused less dysfunction at the photochemical level.
\end{abstract} plants were grown in a nutrient solution containing 0 or $2 \mathrm{mM} \mathrm{Si}(-\mathrm{Si}$ or $+\mathrm{Si}$, respectively) with and without $P$. oryzae inoculation. Blast severity decreased
Additional keywords: fungal infection, Oryza sativa, photosynthesis.
Rice blast, caused by the hemibiotrophic fungus Pyricularia oryzae Cavara (teleomorph Magnaporthe oryzae (Catt.) B. C. Couch), is the most important disease in rice (Oryza sativa L.) (Ou 1980). The blast symptoms occur on leaves, leaf collars, necks, panicles, pedicels, and seed. On the leaves, lesions are initially graygreen and water soaked with a darker green border (Ou 1980). As the lesions expand, they become light tan and develop necrotic borders (Bonman 1992; Ou 1980). The blast lesions that occur on rice collars, necks, and panicles contribute to reduced rice yields due to the reduced translocation of nutrients for grain filling (Bonman 1992). Rice blast has been controlled by treating seed with fungicides, spraying systemic fungicides at different plant growth stages, and using resistant cultivars (Bonman 1992).

The most positive and consistent effects of using soluble silicon (Si) include the alleviation of abiotic and biotic stresses in a wide variety of plant species (Datnoff et al. 2007; Epstein 2009; Fauteux et al. 2005; Liang et al. 2007; Ma et al. 2001). In particular, Si has been recognized for its potential to decrease the intensities of important diseases in several crops, especially in grasses and some dicots, such as bean, cucumber, and soybean (Datnoff et al. 2007; Ma et al. 2001). For the rice- $P$. oryzae interaction, Si can potentiate biochemical mechanisms against the fungus, including increases in the concentrations of phenolics, lignin, and phytoalexins; enhanced

Corresponding author: F. A. Rodrigues; E-mail address: fabricio@ufv.br activities of defense enzymes such as chitinases and $\beta$-1,3-glucanases; and the rapid transcription of genes associated with defense responses (Brunings et al. 2009; Rodrigues et al. 2003, 2004, 2005). Furthermore, increased resistance of plants supplied with $\mathrm{Si}$ against pathogens has been associated with a physical barrier that prevents or slows fungal penetration, For example, a barrier can result from an increase in the density of the long and short silicate cells in the leaf epidermis or in the thick silica layer below the cuticle, as noted for the rice- $P$. oryzae interaction (Kim et al. 2002; Sun et al. 2010; Yoshida et al. 1962).

The lesions caused by hemibiotrophic and necrotrophic pathogens can affect plant physiology by negatively affecting leaf gas exchange due to losses in healthy leaf area or by lowering the efficiency of the photosynthetic process, even in asymptomatic leaf tissues (Alves et al. 2011; Gao et al. 2011; Padhi et al. 1978; Resende et al. 2012; Shtienberg 1992; Swiech et al. 2001; Yun et al. 2000). For different host-pathogen interactions, reductions in the pigment concentrations, structural damage to the chloroplasts, impairments in energy dissipation (which can be determined via chlorophyll $a\left[\mathrm{Chl}_{a}\right]$ fluorescence kinetics), and increases in leaf temperature are the most notable negative effects that result from pathogen infection (Baker 2008; Bastiaans 1991; Bastiaans and Roumen 1993; Krause and Weis 1991; Lichtenthaler and Miehé 1997; Meyer et al. 2001). In addition, pathogens can cause leaf damage at the cuticular and stomatal levels, which can lead to changes in transpiration, the plant water balance, and the plant canopy temperature (Padhi et al. 1978; Resende et al. 2012). Because photosynthesis is the major physiological process that fuels biomass production, any alterations in photosynthesis affect 
crop growth and performance. Therefore, a proper assessment of the photosynthetic apparatus upon pathogen infection (e.g., via measurements of the leaf gas exchange and $\mathrm{Chl}_{a}$ fluorescence kinetics) is very important (Balachandran and Osmond 1994).

Stressful conditions induced by biotic factors can impair photosynthetic performance (Bastiaans 1991; Bastiaans and Roumen 1993; Berger et al. 2007), increase the excitation energy to exceed the amount required for photosynthetic metabolism, and contribute to the generation of reactive oxygen species (ROS) (Resende et al. 2012). The ROS, especially hydrogen peroxide $\left(\mathrm{H}_{2} \mathrm{O}_{2}\right)$, have been recorded to result from the infection process of several pathogens (Shetty et al. 2007; Unger et al. 2005). Broadly, any type of stress occurring on ROSproducing organelles during pathogen infection may contribute to ROS production (Apel and Hirt 2004). An antioxidant system normally maintains the ROS balance within plant cells due to the contribution of the antioxidative enzymes involved in the ROS detoxification, such as superoxide dismutase (SOD), catalase (CAT), ascorbate peroxidase (APX), and glutathione reductase (GR). Other antioxidants, including ascorbate and reduced glutathione, also play a pivotal role in maintaining the ROS pools at controlled levels (Havir and McHale 1989; Mittler 2002; Moller 2001; Nakano and Asada 1981).

Resende et al. (2012) demonstrated that Si can be beneficial for sorghum plants that are infected with Colletotrichum sublineolum, mainly due to greater SOD, CAT, APX, and GR activities. The authors found that $\mathrm{Si}$ was beneficial for the sorghum plants by maintaining carbon fixation and enhancing the antioxidant system, resulting in increased ROS scavenging and, ultimately, reducing cell membrane damage. Mohaghegh et al. (2011) observed greater CAT and APX activities on cucumber roots supplied with $\mathrm{Si}$ and infected with Phytophthora melonis. Sun et al. (2010) observed that rice plants supplied with $\mathrm{Si}$ and infected by Pyricularia oryzae had increased CAT and lipoxygenase activities and lower malondialdehyde concentrations.

Given the facts described above and considering that Si could help maintain the photosynthetic rates in plants infected with foliar pathogens, it was hypothesized that the supply of Si could mitigate the deleterious effects of $P$. oryzae infection in rice leaves and maintain the functionality of the photosynthetic apparatus. To test this hypothesis, the combined gas exchange and $\mathrm{Chl}_{a}$ fluorescence measurements, along with an analysis of the antioxidant system and pigments pools, were used to examine the photosynthetic performance of rice plants supplied with Si during the infection process of $P$. oryzae.

\section{MATERIALS AND METHODS}

Nutrient solution preparation. The nutrient solution was prepared based on Hoagland and Arnon (1950), with some modifications, and included the following macronutrients: $1.0 \mathrm{mM} \mathrm{KNO}_{3}, 0.25 \mathrm{mM}$ $\mathrm{NH}_{4} \mathrm{H}_{2} \mathrm{PO}_{4}, 0.1 \mathrm{mM} \mathrm{NH}_{4} \mathrm{Cl}, 0.5 \mathrm{mM} \mathrm{MgSO}_{4} \cdot 7 \mathrm{H}_{2} \mathrm{O}$, and $1.0 \mathrm{mM}$ $\mathrm{Ca}\left(\mathrm{NO}_{3}\right) \cdot 4 \mathrm{H}_{2} \mathrm{O}$. In addition, the nutrient solution included the following micronutrients: $0.30 \mu \mathrm{M} \mathrm{CuSO}_{4} \cdot 5 \mathrm{H}_{2} \mathrm{O}, 0.33 \mu \mathrm{M} \mathrm{ZnSO}_{4} \cdot 7 \mathrm{H}_{2} \mathrm{O}$, 11.5 $\mu \mathrm{M} \mathrm{H}_{3} \mathrm{BO}_{3}, 3.5 \mu \mathrm{M} \mathrm{MnCl}_{2} \cdot 4 \mathrm{H}_{2} \mathrm{O}, 0.1 \mu \mathrm{M}\left(\mathrm{NH}_{4}\right)_{6} \mathrm{Mo}_{7} \mathrm{O}_{2}$. $4 \mathrm{H}_{2} \mathrm{O}, 25 \mu \mathrm{M} \mathrm{FeSO}_{4} \cdot 7 \mathrm{H}_{2} \mathrm{O}$, and $25 \mu \mathrm{M}$ EDTA disodium. Si was supplied as monosilicic acid, which was prepared by passing potassium silicate through a cation-exchange resin (Amberlite IR-120B, $\mathrm{H}^{+}$form; Sigma-Aldrich, São Paulo, Brazil) (Ma and Yamaji 2006). The Si was applied at $2 \mathrm{mM}$ in the treatments and no Si was applied $(0 \mathrm{mM})$ to the control. The addition of monosilicic acid to the nutrient solution did not alter the $\mathrm{pH}$.

Plant growth. Rice seed from 'Metica-1' were surface-sterilized in $10 \%$ ( $\mathrm{vol} / \mathrm{vol}) \mathrm{NaOCl}$ for $3 \mathrm{~min}$, rinsed in sterilized water for $3 \mathrm{~min}$, and germinated on distilled-water-soaked germitest paper (20 by $20 \mathrm{~cm}$, cellulose at $120 \mathrm{~g} / \mathrm{m}^{2}$; Germilab; BioGenética Ltd., São Paulo, Brazil) in a germination chamber at $25^{\circ} \mathrm{C}$ for 6 days. The germinated seedlings were transferred to plastic pots containing one-half strength nutrient solution without $\mathrm{Si}$ for 5 days. Subsequently, five plants were transferred to new plastic pots containing 5 liters of nutrient solution prepared with or without $\mathrm{Si}$. The nutrient solution was changed every 4 days, and the electrical conductivity and $\mathrm{pH}$ of the nutrient solutions were measured daily. The $\mathrm{pH}$ was maintained at approximately 5.5 by adding $\mathrm{NaOH}$ or $\mathrm{HCl}(1 \mathrm{M})$ as necessary. The plants were grown in a greenhouse with a relative humidity of $65 \pm 5 \%$, a temperature of $30 \pm 5^{\circ} \mathrm{C}$, and a natural photon irradiance of $900 \pm$ $15 \mu \mathrm{mol}$ photons $\mathrm{m}^{-2} \mathrm{~s}^{-1}$ (measured at midday).

Inoculation procedure. A pathogenic isolate of $P$. oryzae (CNPAF-1048) was used to inoculate the plants. Disks of filter paper containing fungal mycelia were transferred to Petri dishes (90 by $15 \mathrm{~mm}$ ) containing oat-agar medium. After growing the disks containing mycelia, the media with the fungus were transferred to new Petri dishes containing the same medium. The dishes were incubated in a growth chamber at $25^{\circ} \mathrm{C}$ under continuous light for 10 days. After this period, conidia were carefully removed from the media with a soft bristle brush using water-containing gelatin $(1 \%$ $\mathrm{wt} / \mathrm{vol}$ ). The conidial suspension was calibrated with a hemacytometer to obtain a concentration of $1 \times 10^{5}$ conidia $\mathrm{ml}^{-1}$. The conidial suspension was sprayed with an atomizer (Paasche Airbrush Co., Chicago) on the adaxial surface of the plant leaves 45 days after emergence. After inoculation, the plants were kept in the dark in a mist chamber at $25^{\circ} \mathrm{C}$ for $24 \mathrm{~h}$. Next, the plants were transferred to a greenhouse with a relative humidity of $80 \pm 5 \%$ and a temperature of $25 \pm 3^{\circ} \mathrm{C}$.

Evaluation of blast severity. The second and third leaves (from the base to the top) of each plant per replication for each treatment were marked and used to evaluate the blast severity at
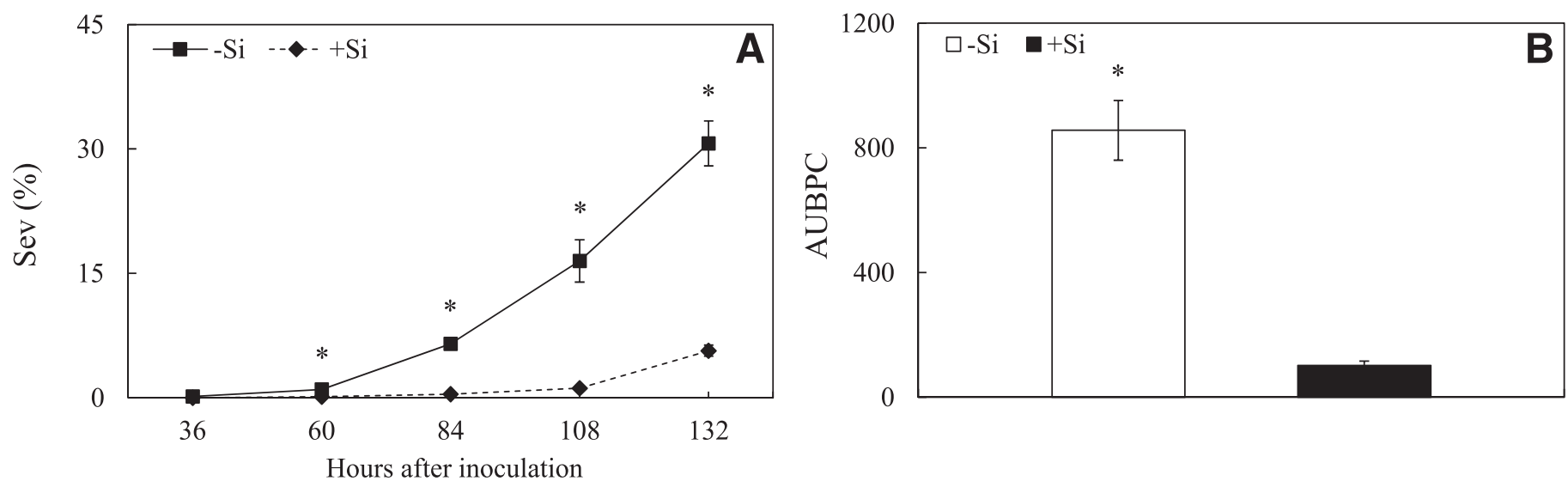

Fig. 1. A, Blast severity (Sev) and B, area under blast progress curves (AUBPC) for rice plants grown in hydroponic culture containing $0 \mathrm{mM}(-\mathrm{Si})$ or $2 \mathrm{mM}(+\mathrm{Si})$ silicon. For blast development, the means for the $-\mathrm{Si}$ and $+\mathrm{Si}$ treatments followed by an asterisk (*) at each evaluation time are significantly different according to a Student's $t$ test $(P \leq 0.05)$. Error bars represent the standard error of the mean. 
$36,60,84,108$, and $132 \mathrm{~h}$ after inoculation (hai) according to the scale proposed by IRRI (1996). The area under the blast progress curve (AUBPC) for each leaf was computed using the trapezoidal integration of the blast progress curve over time (Shaner and Finney 1977).

Photosynthetic measurements. The leaf gas exchange parameters were simultaneously determined by measuring the chlorophyll $a\left(\mathrm{Chl}_{a}\right)$ fluorescence with a portable open-flow gas exchange system (LI-6400XT; LI-COR, Lincoln, NE) equipped with an integrated fluorescence chamber head (LI-6400-40; LI-COR Inc.). The net $\mathrm{CO}_{2}$ assimilation rate $(A)$, stomatal conductance to water vapor $\left(g_{\mathrm{s}}\right)$, internal-to-ambient $\mathrm{CO}_{2}$ concentration ratio $\left(C_{\mathrm{i}} / C_{\mathrm{a}}\right)$, and transpiration rate $(E)$ were measured on the attached leaves (fourth leaf from the top of the plant for each replication of each treatment) at approximately 08:00 $\mathrm{h}(0,36,60,84,108$, and 132 hai) and $12: 00 \mathrm{~h}$ (solar time) $(0,42,66,90$, and 114 hai) with a saturating
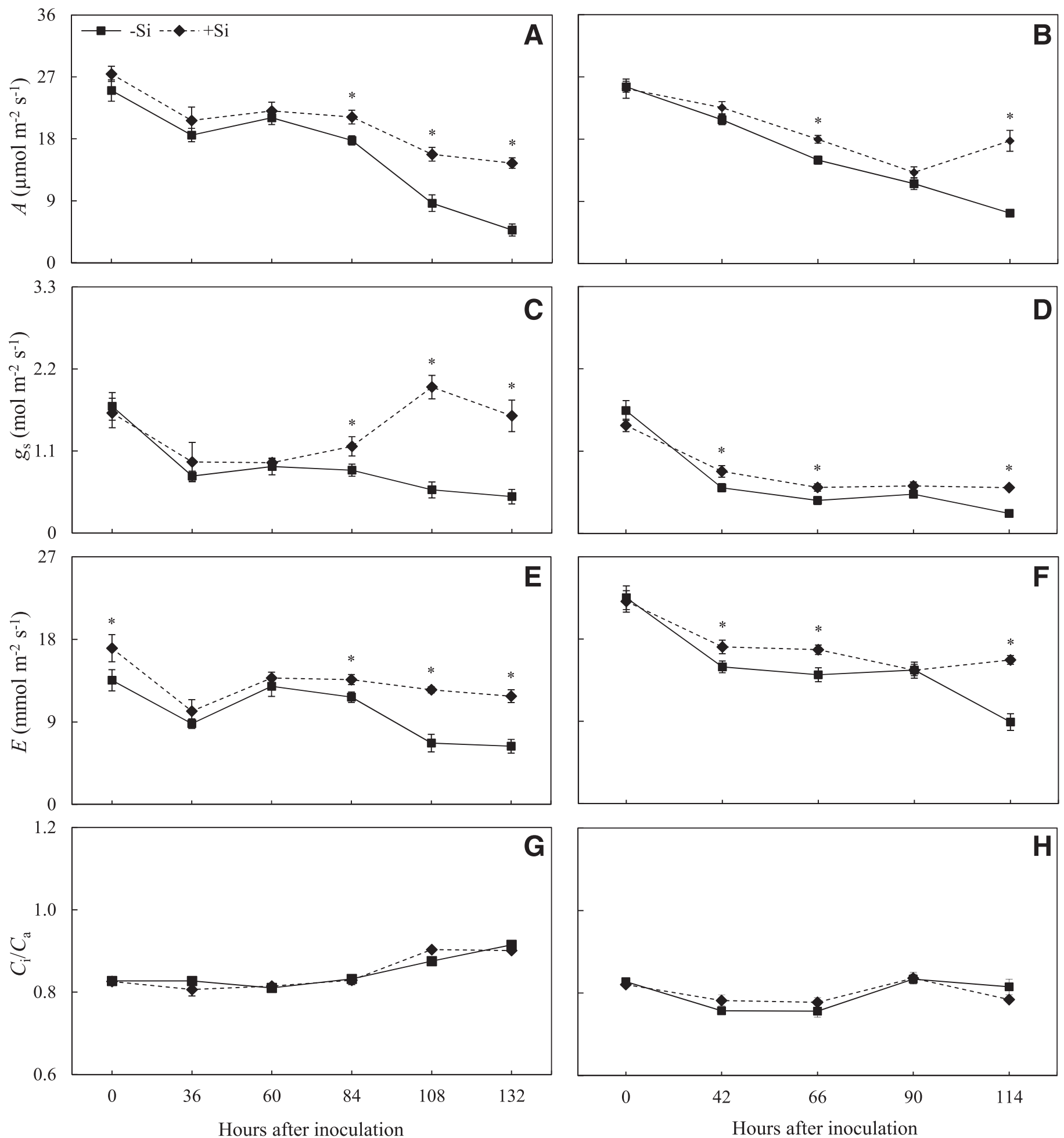

Fig. 2. A and $\mathbf{B}$, Net carbon assimilation rate $(A)$; $\mathbf{C}$ and $\mathbf{D}$, stomatal conductance to water vapor $\left(g_{\mathrm{s}}\right) ; \mathbf{E}$ and $\mathbf{F}$, transpiration rate $(E)$; and $\mathbf{G}$ and $\mathbf{H}$, the internal-toambient $\mathrm{CO}_{2}$ concentration ratio $\left(C_{\mathrm{i}} / C_{\mathrm{a}}\right)$ determined at $08: 00 \mathrm{~h}(\mathrm{~A}, \mathrm{C}, \mathrm{E}$, and $\mathrm{G})$ and at 12:00 h $(\mathrm{B}, \mathrm{D}, \mathrm{F}$, and $\mathrm{H})$ in the leaves of rice plants grown in hydroponic culture containing $0 \mathrm{mM}(-\mathrm{Si})$ or $2 \mathrm{mM}(+\mathrm{Si})$ silicon and inoculated with Pyricularia oryzae. Bars represent the standard error and asterisks indicate the means that differed significantly at each evaluation time $(t$ test, $P \leq 0.05)$. 
photon irradiance of approximately $1,200 \mu \mathrm{mol} \mathrm{m} \mathrm{m}^{-2} \mathrm{~s}^{-1}$ at the leaf level under the naturally fluctuating ambient $\mathrm{CO}_{2}$ concentrations. All of the measurements were performed at $25^{\circ} \mathrm{C}$ and the vapor pressure deficit was maintained at approximately $1.0 \mathrm{kPa}$. The amount of blue light was set to $10 \%$ of the photon irradiance to optimize the stomatal aperture.
Previously dark-adapted (30 min) leaf tissues were illuminated with weak modulated measuring beams $\left(0.03 \mu \mathrm{mol} \mathrm{m} \mathrm{m}^{-2} \mathrm{~s}^{-1}\right)$ to obtain the initial fluorescence $\left(F_{0}\right)$. Saturating white light pulses of $8,000 \mu \mathrm{mol}$ photons $\mathrm{m}^{-2} \mathrm{~s}^{-1}$ were applied for $0.8 \mathrm{~s}$ to ensure maximum fluorescence emissions $\left(F_{\mathrm{m}}\right)$. The variable-to-maximum Chl fluorescence ratio $\left.F_{\mathrm{v}} / F_{\mathrm{m}}=\left[\left(F_{\mathrm{m}}-F_{0}\right) / F_{\mathrm{m}}\right)\right]$ was calculated from
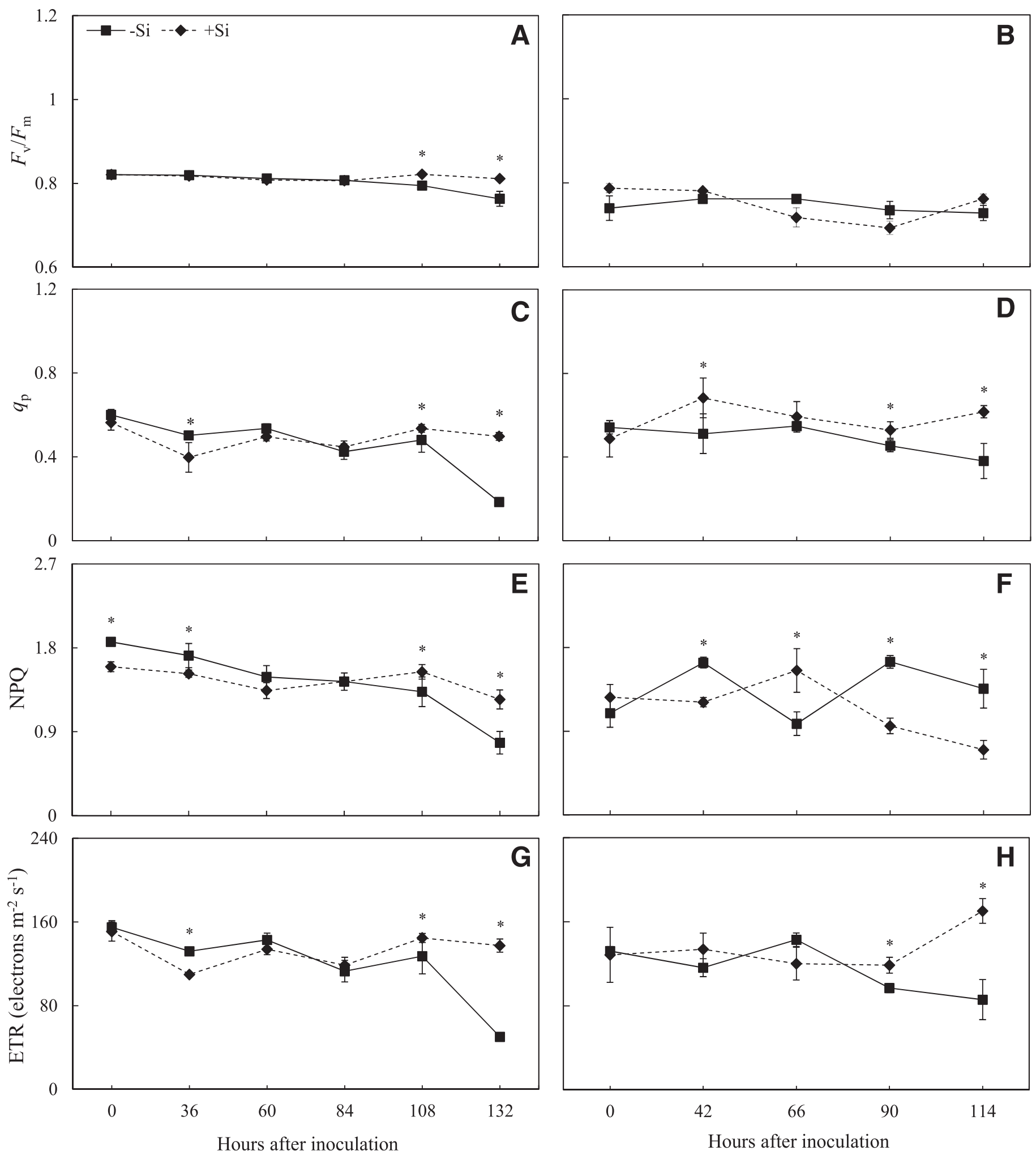

Fig. 3. A and B, Maximum photochemical efficiency of photosystem II (PSII) $\left(F_{\mathrm{v}} / F_{\mathrm{m}}\right)$; C and D, photochemical $\left(q_{\mathrm{p}}\right)$ and $\mathbf{E}$ and $\mathbf{F}$, nonphotochemical (NPQ) quenching coefficients; and $\mathbf{G}$ and $\mathbf{H}$, the electron transport rate (ETR) determined at 08:00 h (A, C, E, and G) and at 12:00 h (B, D, F, and H) in the leaves of rice plants grown in hydroponic culture containing $0 \mathrm{mM}(-\mathrm{Si})$ or $2 \mathrm{mM}(+\mathrm{Si})$ silicon and inoculated with Pyricularia oryzae. Bars represent the standard error and asterisks indicate the means that differed significantly for each evaluation point $(t$ test, $P \leq 0.05)$. 
$F_{\mathrm{m}}$. In the light-adapted leaves, the steady-state fluorescence yield $\left(F_{\mathrm{s}}\right)$ was measured following the application of a saturating white light pulse $\left(8,000 \mu \mathrm{mol} \mathrm{m} \mathrm{m}^{-2} \mathrm{~s}^{-1} ; 0.8 \mathrm{~s}\right)$ to achieve the maximum light-adapted fluorescence $\left(F_{\mathrm{m}}{ }^{\prime}\right)$. Next, the actinic light was turned off and far-red illumination was applied $\left(2 \mu \mathrm{mol} \mathrm{m}^{-2} \mathrm{~s}^{-1}\right)$ to measure the light-adapted initial fluorescence $\left(F_{0}{ }^{\prime}\right)$. Using these parameters, the efficiency of the PSII reaction centers for capturing excitation energy $\left(F_{\mathrm{v}}{ }^{\prime} / F_{\mathrm{m}}{ }^{\prime}\right)$ was estimated as $F_{\mathrm{v}}{ }^{\prime} / F_{\mathrm{m}}{ }^{\prime}=\left(F_{\mathrm{m}}{ }^{\prime}-F_{0}{ }^{\prime}\right) / F_{\mathrm{m}}{ }^{\prime}$. The coefficient for photochemical quenching $\left(q_{\mathrm{P}}\right)$ was calculated as $q_{\mathrm{P}}=$ $\left(F_{\mathrm{m}}{ }^{\prime}-F_{\mathrm{s}}\right) /\left(F_{\mathrm{m}}{ }^{\prime}-F_{0}{ }^{\prime}\right)$, while that for nonphotochemical quenching (NPQ) was calculated as NPQ $=\left(F_{\mathrm{m}} / F_{\mathrm{m}}{ }^{\prime}\right)-1$. The actual quantum yield of PSII electron transport $\left(\Phi_{\mathrm{PSII}}\right)$ was computed as $\Phi_{\mathrm{PSII}}=$ $\left(F_{\mathrm{m}}{ }^{\prime}-F_{\mathrm{s}}\right) / F_{\mathrm{m}}{ }^{\prime}$, from which the apparent electron transport rate (ETR) was calculated as ETR $=\Phi_{\text {PSII }} \times$ PPFD $\times f \times \alpha$, where $f$ is a factor that accounts for the partitioning of energy between PSII and PSI and is assumed to be 0.5 , which indicates that the excitation energy is distributed equally between the two photosystems, and $\alpha$ is the leaf absorbance by the photosynthetic tissues and is assumed to be 0.84 (Baker 2008).

Determination of leaf pigments. Leaf tissue $(0.5 \mathrm{~g})$ was ground into a fine powder using a mortar and pestle with liquid nitrogen and $1 \mathrm{mg}$ of calcium carbonate. Next, the fine powder was homogenized in $2 \mathrm{ml}$ of aqueous acetone ( $80 \%$, vol/vol) for $1 \mathrm{~min}$ in a room with reduced light intensity $\left(12 \mu \mathrm{mol} \mathrm{m}^{-2} \mathrm{~s}^{-1}\right)$. The suspension was filtered through a Whatman number 1 filter paper and the residue was washed four times with $80 \%$ acetone. The volume was adjusted to $25 \mathrm{ml}$ using the same solvent in a volumetric flask. The absorbance of the samples was recorded at 470,646.8, and $663.2 \mathrm{~nm}$, and the concentrations of photosynthetic pigments $\left(\mathrm{Chl}_{a}, \mathrm{Chl}_{b}\right.$, and total carotenoids) were estimated according to Lichtenthaler (1987).

Biochemical assays. Samples from the fourth and fifth leaves (from the top to the base) of each plant in each replication and treatment were collected at $36,60,84,108$, and 132 hai at approximately 12:00 h. The leaf samples collected from noninoculated plants served as a control (0 hai). The leaf samples were kept in liquid nitrogen during sampling and were stored at $-80^{\circ} \mathrm{C}$ until analysis.

To determine the SOD (EC 1.15.1.1), CAT (EC 1.11.1.6), APX (EC 1.11.1.11), GR (EC 1.8.1.7), and lypoxigenase (LOX) (EC 1.13.11.12) activities, $200 \mathrm{mg}$ of leaf tissue was ground into a fine powder in a mortar and pestle with liquid nitrogen. The fine powder was homogenized in an ice bath with $60 \mathrm{mg}$ of polyvinylpolypyrrolidone and the following components: for SOD, $1 \mathrm{ml}$ of $100 \mathrm{mM}$ potassium phosphate buffer ( $\mathrm{pH}$ 7.8), $0.1 \mathrm{mM}$ EDTA, and $0.1 \%$ Triton X-100 (vol/vol); for CAT, $1 \mathrm{ml}$ of $100 \mathrm{mM}$ potassium phosphate buffer ( $\mathrm{pH} 7.0)$ and $0.1 \mathrm{mM}$ EDTA; for APX, $1 \mathrm{ml}$ of $50 \mathrm{mM}$ potassium phosphate buffer $(\mathrm{pH} 7.0)$ and $1 \mathrm{mM}$ ascorbate; for GR, $1 \mathrm{ml}$ of $100 \mathrm{mM}$ Tris-HCl (pH 7.5), $50 \mathrm{mM}$ EDTA, $10 \mathrm{mM}$ isoascorbate, $9 \mathrm{mM}$ 2-mercaptoethanol, and $0.1 \%$ Triton $\mathrm{X}-100$ (vol/vol); and, for LOX, $2 \mathrm{ml}$ of $50 \mathrm{mM}$ potassium phosphate buffer (pH 7.0) and $1 \mathrm{mM}$ hydroxylamine. For SOD, CAT, APX, and GR, the homogenates were centrifuged at $15,000 \times g$ for $15 \mathrm{~min}$ at $4^{\circ} \mathrm{C}$ and the supernatants were used as crude enzyme extracts. For LOX, the homogenate was centrifuged at $16,000 \times g$ for $20 \mathrm{~min}$ at $4^{\circ} \mathrm{C}$, and the supernatants were used as crude enzyme extracts. The SOD activity was determined by measuring its ability to photochemically reduce $p$-nitrotetrazol blue (NTB) (Giannopolitis and Ries 1977). The reaction was started by adding $5 \mu \mathrm{l}$ of the crude enzyme extract to $3 \mathrm{ml}$ of a mixture containing $50 \mathrm{mM}$ potassium phosphate buffer (pH 7.8), $14 \mathrm{mM}$ methionine, $75 \mu \mathrm{M}$ NTB, $0.1 \mu \mathrm{M}$ EDTA, and $2 \mu \mathrm{M}$ riboflavin. The production of formazan blue, resulting from the photoreduction of NTB, was monitored as the increase in absorbance at $560 \mathrm{~nm}$ (Giannopolitis and Ries 1977). One unit of SOD was defined as the amount of enzyme necessary to inhibit NTB photoreduction by $50 \%$. The CAT activity was estimated from the rate of $\mathrm{H}_{2} \mathrm{O}_{2}$ decomposition at $240 \mathrm{~nm}$ (Havir and McHale 1989). The reaction was initiated after adding $20 \mu \mathrm{l}$ of the crude enzyme extract to $3 \mathrm{ml}$ of a mixture containing $50 \mathrm{mM}$ potassium phosphate buffer (pH 7.8) and $12.5 \mathrm{mM} \mathrm{H}_{2} \mathrm{O}_{2}$. For APX, the reaction was started after adding $20 \mu \mathrm{l}$ of the crude enzyme extract to $3 \mathrm{ml}$ of a mixture containing $50 \mathrm{mM}$ potassium phosphate buffer $(\mathrm{pH} 7.0)$, $0.5 \mathrm{mM}$ ascorbate, and $0.1 \mathrm{mM} \mathrm{H} \mathrm{H}_{2}$. The APX activity was determined from the rate of ascorbate oxidation at $290 \mathrm{~nm}$ (Nakano and Asada 1981), and the GR activity was determined from the rate of NADPH oxidation at $340 \mathrm{~nm}$. The reaction was initiated after adding $20 \mu \mathrm{l}$ of the crude enzyme extract to a mixture containing $50 \mathrm{mM}$ Tris- $\mathrm{HCl}(\mathrm{pH} 7.5), 10 \mathrm{mM}$ reduced glutathione, $3 \mathrm{mM}$ $\mathrm{MgCl}_{2}$, and $0.15 \mathrm{mM} \mathrm{NADPH}$. For each enzyme, six separate extractions were performed using samples from each treatment and
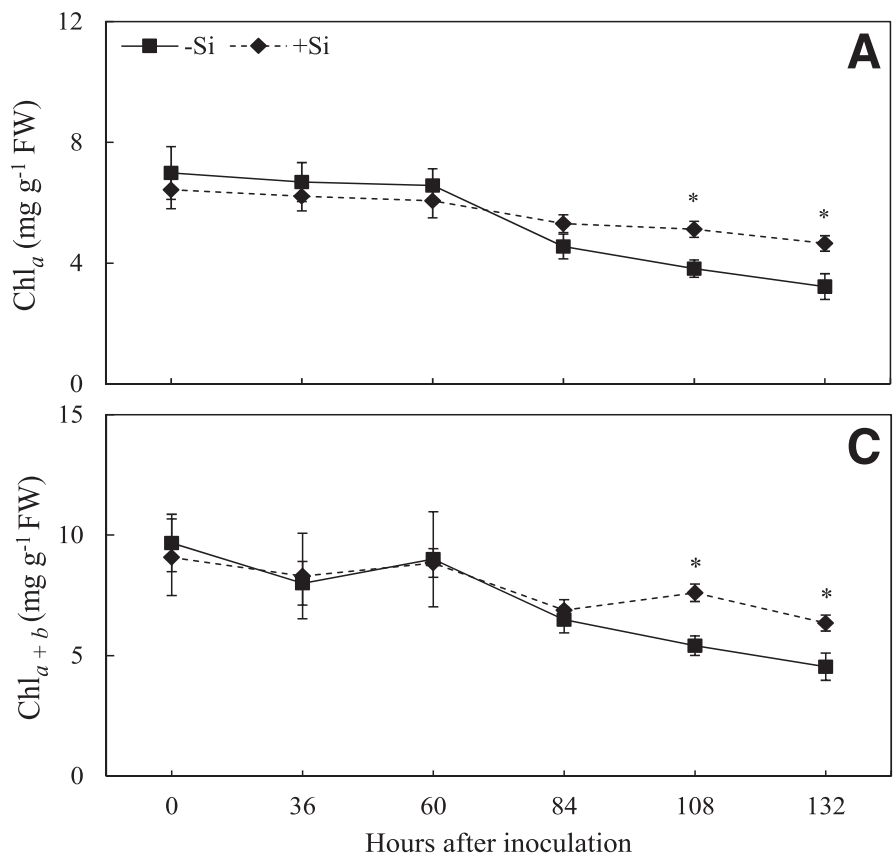
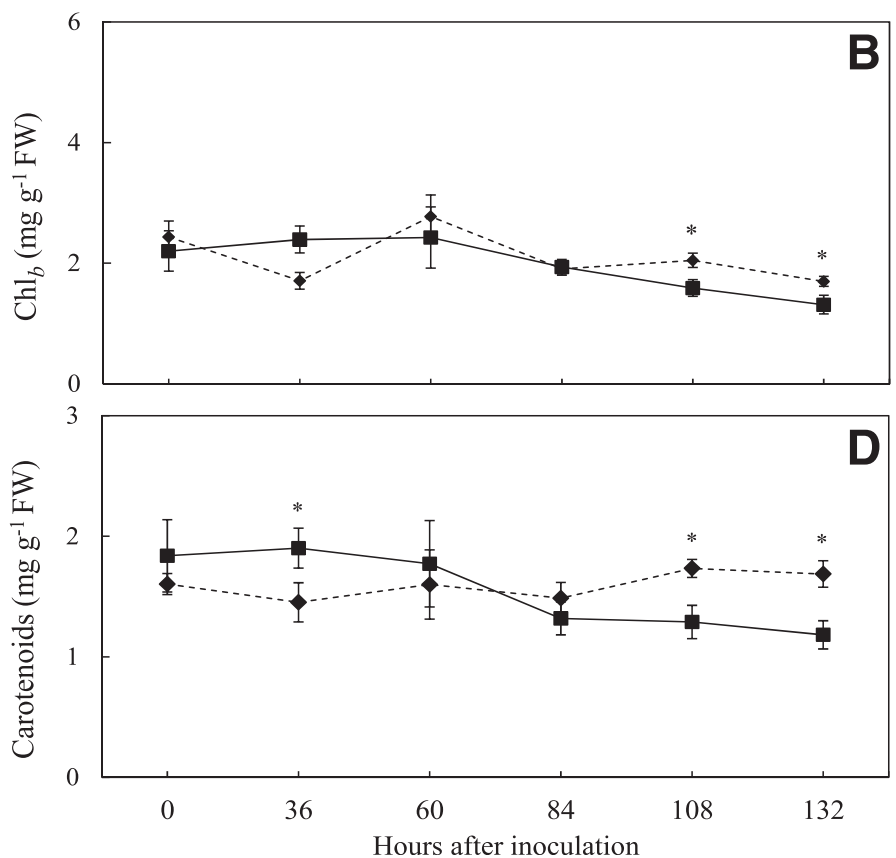

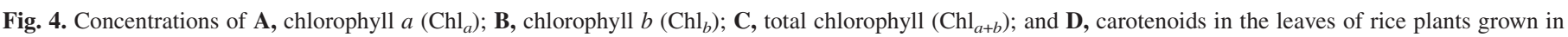

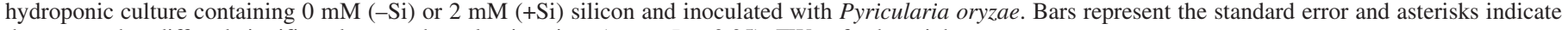
the means that differed significantly at each evaluation time $(t$ test, $P \leq 0.05)$. FW $=$ fresh weight. 
each reaction was performed three times. The LOX activity was determined after adding $50 \mu \mathrm{l}$ of the supernatant to a mixture containing $50 \mathrm{mM}$ sodium phosphate buffer $(\mathrm{pH} 6.5)$ and $50 \mu \mathrm{M}$ sodium linoleate ( $\mathrm{pH}$ 6.0) to obtain a total volume of $1 \mathrm{ml}$. The absorbance of the reaction mixture was recorded every $30 \mathrm{~s}$ over $120 \mathrm{~s}$ at $234 \mathrm{~nm}$ (Axelrod et al. 1981). The soluble protein concentrations on the extracts were measured using the method described by Bradford (1976).

The $\mathrm{H}_{2} \mathrm{O}_{2}$ concentration was determined by grinding $200 \mathrm{mg}$ of leaf tissue into a fine powder in a mortar and pestle with liquid nitrogen. The fine powder was homogenized in an ice bath in $2 \mathrm{ml}$ of $50 \mathrm{mM}$ potassium phosphate buffer $(\mathrm{pH} 6.5)$ containing $1 \mathrm{mM}$ hydroxylamine. The homogenate was centrifuged at $10,000 \times g$ for $15 \mathrm{~min}$ at $4^{\circ} \mathrm{C}$ (Kuo and Kao 2003) and the supernatant was used to determine the $\mathrm{H}_{2} \mathrm{O}_{2}$ concentration. The reaction was initiated after adding $50 \mu \mathrm{l}$ of the supernatant to a mixture containing $25 \mathrm{mM}$ sulfuric acid, $250 \mu \mathrm{M}$ ammonium ferrous sulfate, $250 \mu \mathrm{M}$ xylenol orange, and $100 \mathrm{mM}$ sorbitol to obtain a total volume of $2 \mathrm{ml}$ (Gay and Gebicki 2000). The samples were stored in the dark for $30 \mathrm{~min}$ and the absorbance was recorded at $560 \mathrm{~nm}$. Control samples (blank) for the color of the reagents and for the sample extracts were prepared concurrently with the test samples and subtracted from the absorbance of each sample.

The oxidative damage to the lipids was estimated as the concentration of the total 2-thiobarbituric acid (TBA)-reactive substances and expressed as equivalents of malondialdehyde (MDA) according to Cakmak and Horst (1991), with few modifications. Briefly, $200 \mathrm{mg}$ of leaf tissue was homogenized in $2 \mathrm{ml}$ of $0.1 \%$ (wt/vol) trichloroacetic acid (TCA) solution at $4{ }^{\circ} \mathrm{C}$. After centrifugation at $10,000 \times g$ for $15 \mathrm{~min}, 0.5 \mathrm{ml}$ of the supernatant was reacted with $1.5 \mathrm{ml}$ of TBA $(0.5 \%$ in $20 \%$ TCA) for $20 \mathrm{~min}$ in a boiling water bath. Next, the reaction was stopped by immersion in an ice bath. The samples were centrifuged at $13,000 \times g$ for $4 \mathrm{~min}$ and the absorbance of the supernatant was recorded at $532 \mathrm{~nm}$. The concentrations of MDA formed in each sample were calculated by using an extinction coefficient of $155 \mathrm{mM}^{-1} \mathrm{~cm}^{-1}$.

Determination of the foliar Si concentration. At the end of the blast severity experiment, the leaves were collected from the plants of each replication and each treatment, washed in deionized water, dried for $72 \mathrm{~h}$ at $65^{\circ} \mathrm{C}$, and ground to pass through a 40-mesh screen using a Thomas Wiley mill (Thomas Scientific, Swedesboro, NJ). The foliar Si concentration was determined by colorimetric analysis using $0.1 \mathrm{~g}$ of dried and alkali-digested tissue (Korndörfer et al. 2004).

Experimental design and data analyzes. An experiment consisting of two Si concentrations ( 0 or $2 \mathrm{mM}$, hereafter referred to as the $-\mathrm{Si}$ and $+\mathrm{Si}$ plants, respectively) arranged in a completely randomized design with 10 replications was used to evaluate the blast severity and the foliar Si concentration. The photosynthetic measurements were obtained from an experiment consisting of two $\mathrm{Si}$ concentrations arranged in a completely randomized design with 10 replications. In addition, leaf samples were obtained from these experiments for the biochemical assays. The analysis of variance for these experiments was used to test two $\times$ six factors consisting of two $\mathrm{Si}$ concentrations and six evaluation times (photosynthetic measurements) and six sampling times (biochemical assays). Each experimental unit consisted of a plastic pot with five plants, and all experiments were repeated once. Data from the AUBPC and foliar Si concentration were pooled based on Bartlett's test, which was used to determine whether the replications from the two experiments were from populations with equal variances. The mean comparisons of the treatments were obtained by conducting a Student's $t$ test $(P \leq 0.05)$ using SAS (SAS Institute, Inc., Cary, NC). The blast severity and the photosynthetic measurements were correlated using Pearson's linear correlation analysis.

\section{RESULTS}

Foliar Si concentration. The foliar Si concentration significantly increased by $683 \%$ for the $+\mathrm{Si}$ plants relative to the $-\mathrm{Si}$ plants (47 and $6 \mathrm{~g} \mathrm{~kg}^{-1}$, respectively).
Blast severity and AUBPC. The blast severity was significantly higher on the leaves of the -Si plants relative to the leaves of the $+\mathrm{Si}$ plants from 60 to 132 hai (Fig. 1A). The AUBPC was reduced by $89 \%$ for the + Si plants in comparison with the - Si plants (Fig. 1B).

Leaf gas exchange parameters. Overall, the values of $A, g_{\mathrm{s}}$, and $E$ were greater for the + Si plants than for the - Si plants upon P. oryzae infection at 08:00 and $12: 00 \mathrm{~h}$ (Fig. 2). In the early morning $(08: 00 \mathrm{~h})$, when the gas exchange performance is less affected by the prevailing environmental conditions and the applied treatments are more accurately affected, the $A$ and $g_{\text {s }}$ values were significantly higher at 84, 108, and 132 hai (Fig. 2A and $C$ ) and the $E$ value was significantly higher at $0,84,108$, and 132 hai (Fig. 2E) for the + Si plants relative to the - Si plants. At 12:00 h, $A$ was significantly higher at 66 and 144 hai (Fig. 2B), while $g_{\mathrm{s}}$ and $E$ were higher at 42, 66, and 114 hai (Fig. 2D and F) for the $+\mathrm{Si}$ plants relative to the $-\mathrm{Si}$ plants. There was no changes in the $C_{\mathrm{i}} / C_{\mathrm{a}}$ ratio for the $-\mathrm{Si}$ and $+\mathrm{Si}$ plants at $08: 00$ or 12:00 $\mathrm{h}$ (Fig. $2 \mathrm{G}$ and $\mathrm{H})$.

Photochemical parameters. At 08:00 h, the $F_{\mathrm{v}} / F_{\mathrm{m}}, q_{p}$, NPQ, and ETR values were higher for the +Si plants than for the - Si plants
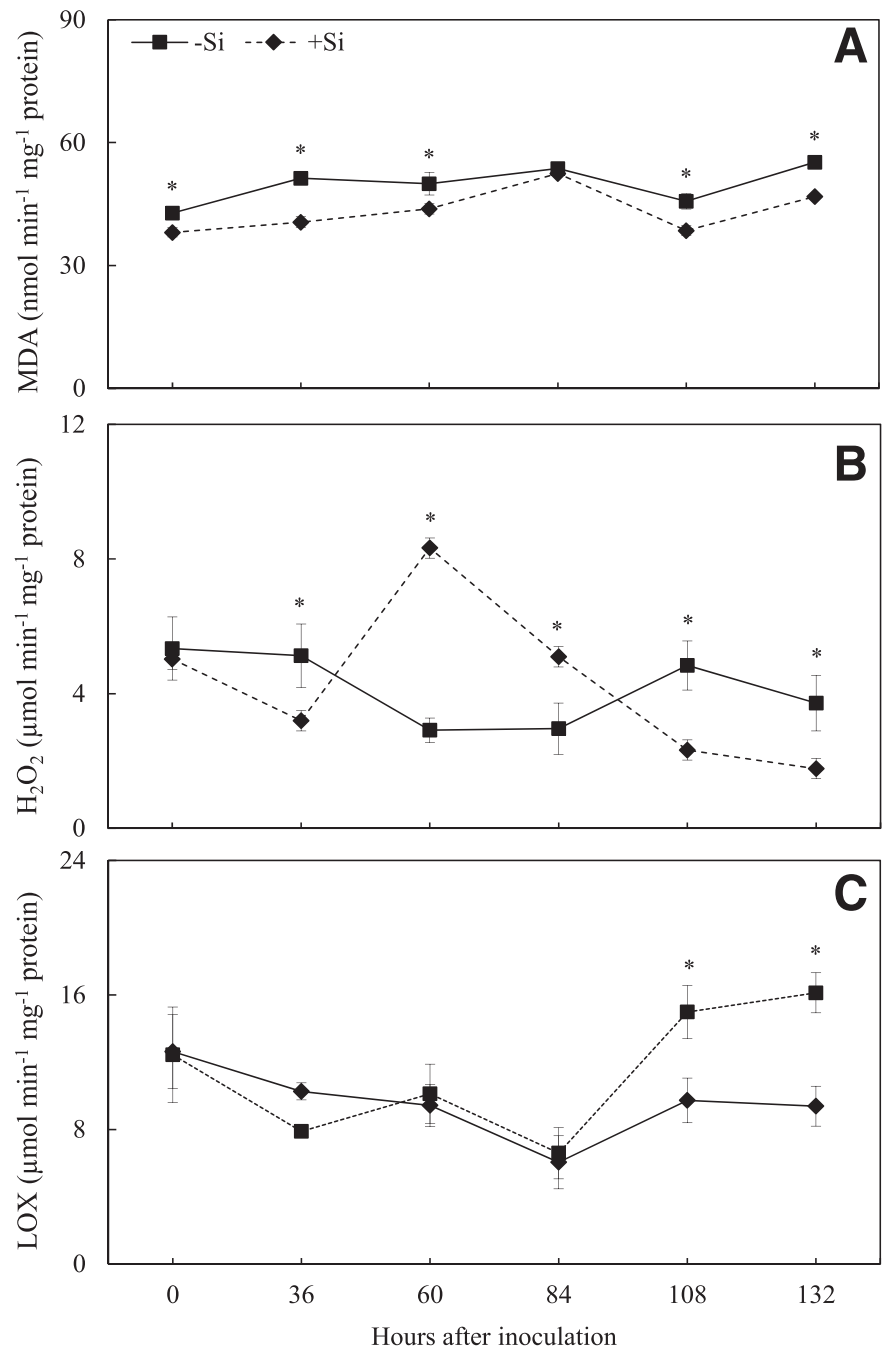

Fig. 5. Concentration of A, malondialdehyde (MDA); $\mathbf{B}$, concentration of hydrogen peroxide $\left(\mathrm{H}_{2} \mathrm{O}_{2}\right)$; and $\mathbf{C}$, lypoxygenase (LOX) activity in the leaves of rice plants grown in hydroponic culture containing $0 \mathrm{mM}(-\mathrm{Si})$ or $2 \mathrm{mM}$ $(+\mathrm{Si})$ silicon and inoculated with Pyricularia oryzae. Means for the $-\mathrm{Si}$ and $+\mathrm{Si}$ treatments followed by an asterisk $(*)$ for each evaluation time are significantly different according to a Student's $t$ test $(P \leq 0.05)$. Error bars represent the standard error of the mean. 
at 108 and 132 hai (Fig. 3A, C, E, and G). The $q_{\mathrm{p}}$ and ETR values were significantly higher for the $-\mathrm{Si}$ plants than for the $+\mathrm{Si}$ plants at 36 hai (Fig. 3C and G) and at 0 and 36 hai for NPQ (Fig. 3C). At $12: 00 \mathrm{~h}$, the $q_{\mathrm{p}}, \mathrm{NPQ}$, and ETR values were significantly lower for the + Si plants in comparison with the $-\mathrm{Si}$ plants at 42, 90, 114 (Fig. 3D), 66 (Fig. 3F), 90, and 114 hai (Fig. 3H), respectively. In comparison with the $+\mathrm{Si}$ plants, the NPQ for the $-\mathrm{Si}$ plants was significantly higher at 42, 90, and 114 hai (Fig. 3F).

Photosynthetic pigments. The concentrations of the carotenoids and $\mathrm{Chl}_{a}, \mathrm{Chl}_{b}$, and $\mathrm{Chl}_{a+b}$ were significantly greater for the + Si plants than the - Si plants at 108 and 132 hai (Fig. 4A-D). For the -Si plants, the carotenoid concentration was significantly higher at 36 hai in comparison with the + Si plants (Fig. 4D).

MDA and $\mathrm{H}_{2} \mathrm{O}_{2}$ concentrations. The MDA concentration was significantly higher for the $-\mathrm{Si}$ plants than for the + Si plants at $0,36,60,108$, and 132 hai (Fig. 5A). For the -Si plants, the $\mathrm{H}_{2} \mathrm{O}_{2}$ concentration was significantly higher at 36,108 , and 132 hai in comparison with the $+\mathrm{Si}$ plants, and was significantly lower for the + Si plants at 60 and 84 hai (Fig. 5B).

Enzyme activities. The LOX activity was significantly higher at 108 and 132 hai for the $+\mathrm{Si}$ plants compared with the -Si plants (Fig. 5C). The SOD and GR activities were significantly higher for the - Si plants than for the + Si plants at 36 and 84 hai (Fig. 6A) and at 84 hai (Fig. 6D), respectively. The CAT and APX activities were significantly higher for the $+\mathrm{Si}$ plants than for the - Si plants at 84 and 108 hai (Fig. 6B) and at 108 hai (Fig. 6C), respectively.

Pearson correlations. At 08:00 h, the $E$ was positively correlated with the $A$ and $g_{\mathrm{s}}$. In addition, $C_{\mathrm{i}} / C_{\mathrm{a}}$ was negatively correlated with $A$ and with $E$ and positively correlated with $g_{\mathrm{s}}$, and the blast severity was negatively correlated with $A$ and positively correlated with $C_{\mathrm{i}} / C_{\mathrm{a}}$ (Table 1 ). At 12:00 h, the blast severity was negatively correlated with $E$. In addition, $g_{\mathrm{s}}$ was positively correlated with $E$ and $C_{\mathrm{i}} / C_{\mathrm{a}}$. Furthermore, $A$ was positively correlated with $E$ and $g_{\text {s }}$ (Table 1).

\section{DISCUSSION}

This study supports previous findings that $\mathrm{Si}$ can increase the resistance of several monocots against foliar pathogens (Datnoff et al. 2007; Domiciano et al. 2010; Fauteux et al. 2005; Resende et al. 2012), including the resistance of rice to blast (Rodrigues et al. 2003, 2004, 2005; Seebold et al. 2001). To the best of our knowledge, this study is the first to describe the physiological features associated with increases in rice resistance against $P$. oryzae infection due to the presence of Si. Very few studies have evaluated the effects of $\mathrm{Si}$ on the physiological processes of plants under pathogen infections (Gao et al. 2011; Mohaghegh et al. 2011; Resende et al. 2012). However, because the infection process of a certain pathogen is a dynamic event, data obtained at a single time point may not properly reflect what happens to the host physiology upon pathogen infection.

The gas exchange performance of the-Si plants was dramatically impaired over the course of $P$. oryzae infection. However, in the presence of $\mathrm{Si}$ (the $+\mathrm{Si}$ counterparts), these impairments were reduced. Overall, Si per se provoked negligible if any effect on the physiological parameters measured in this study, as noted for the + Si plants at 0 hai. Many studies have reported that fungal infections negatively affect $A$ due to the physical limitations of $\mathrm{CO}_{2}$ influx (Berger et al. 2007; Chou et al. 2000; Resende et al. 2012). Regarding blast, the disintegration of cells in the necrotic tissue of the lesions due to nonhost selective toxins can reduce the transport of water and photoassimilates (Yoshii 1937) and potentially trigger
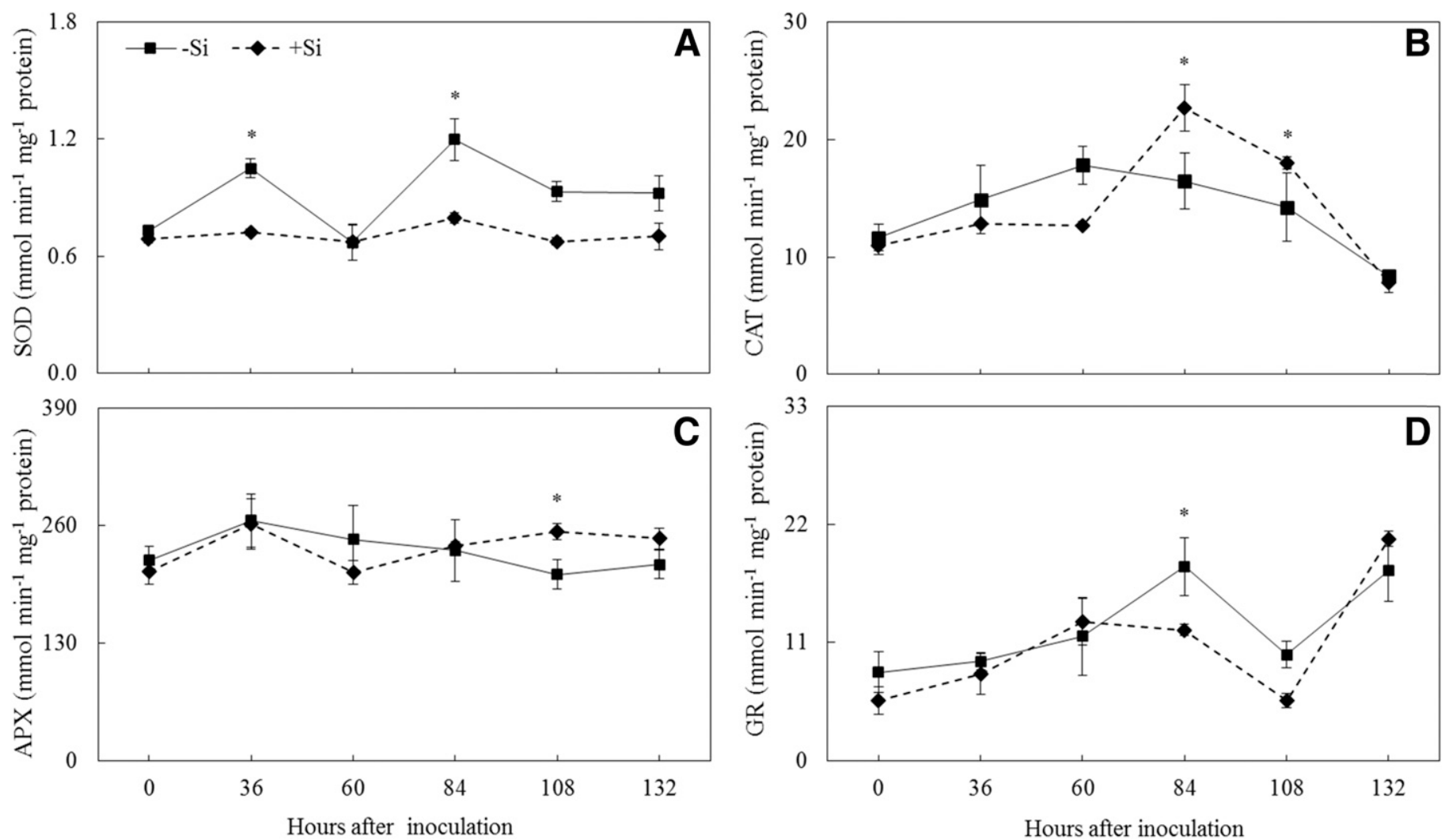

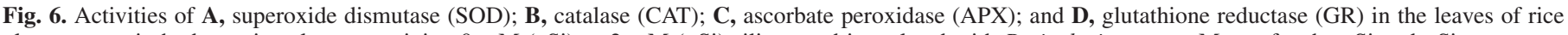

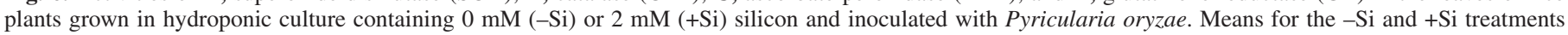

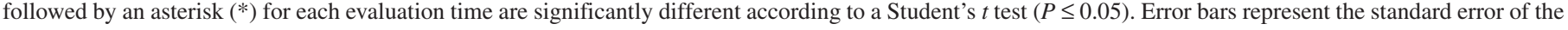
mean. 
stomatal closure, decreasing the $\mathrm{CO}_{2}$ influx into the leaf. Nevertheless, stomatal limitations to photosynthesis should be dismissed in this study. In the early morning (08:00 h), when the magnitude of the gas exchange is less affected by environmental conditions, changes in the $A$ did not correspond with the changes in the $g_{\mathrm{s}}$. Instead, the $A$ was negatively correlated with the $C_{\mathrm{i}} / C_{\mathrm{a}}$ ratio. Together, these results indicate that the decreases in $A$ over the course of blast development were not strongly associated with diffusive (stomatal) limitations to photosynthesis. Furthermore, the $g_{\mathrm{s}}$ values were generally greater than $0.5 \mathrm{~mol} \mathrm{~m} \mathrm{~m}^{-2} \mathrm{~s}^{-1}$, which was more than sufficient for supporting the $A$ values (Detmann et al. 2012). Thus, the changes in $A$ were likely not driven by the changes in $g_{\mathrm{s}}$. Although the $A$ was positively correlated with $g_{\mathrm{s}}$ even at midday, no significant correlation was observed between the $A$ and $C_{\mathrm{i}} / C_{\mathrm{a}}$ ratio, indicating that stomatal limitations did not significantly affect the photosynthetic performance of the rice leaves.

It is possible that the diffusional limitations at the mesophyll level had little impact on the magnitude of the $A$, given that the $C_{\mathrm{i}} / C_{\mathrm{a}}$ ratio increased with time (particularly at 08:00 h). Therefore, biochemical dysfunctions at the chloroplast level likely played a primary role in constraining the $A$ upon infection by $P$. oryzae. In addition, similar results were reported by other authors when measuring the gas exchange parameters for the interactions of hemibiotrophic Mycosphaerella spp.-Eucalyptus globulus and wheat-P. oryzae (Aucique-Perez et al. 2014; Debona et al. 2014; Pinkard and Mohammed 2006) and biotrophic Puccinia psidiiE. urophylla (Alves et al. 2011).

Pyricularia oryzae can release lytic enzymes and nonhost selective toxins into the leaf tissues that could impair carbon fixation reactions or reduce the concentrations of photosynthetic pigments (Aver'yanov et al. 2007), as noted in the present study. These dysfunctions could be mitigated in the presence of Si given that the physical barrier formed on the rice leaf blades following $\mathrm{Si}$ deposition (Yoshida et al. 1962) should contribute to the preservation and functionality of the photosynthetic apparatus in the +Si plants. In addition, because the impairments in the $A$ of rice leaf tissues infected by $P$. oryzae may occur in asymptomatic tissues (Bastiaans 1991), the higher $A$ values likely resulted from the maintenance of adequate carbon fixation rates in the asymptomatic tissues which made up a greater proportion of leaf tissue.

Overall, changes in photosynthesis photochemistry were more prominent at the advanced stages of fungal infection, which were only evident for the $-\mathrm{Si}$ plants. These results involved the following changes: (i) decreases in the $q_{\mathrm{P}}$, suggesting that a lower fraction of the absorbed light was dissipated photochemically or that an increased proportion of oxidized $\mathrm{Q}_{\mathrm{A}}$ was present (which represents the fraction of the PSII centers that are prone to suffer photoinhibitory damage) (Lima et al. 2002); (ii) decreases in the NPQ, which corresponds with lower thermal dissipation of excess energy (Logan et al. 2007); and (iii) dramatic decreases in the ETR during

TABLE 1. Pearson's correlation coefficients among the net carbon assimilation rate $(A)$, stomatal conductance to water vapor $\left(g_{\mathrm{s}}\right)$, transpiration rate $(E)$, internal-to-ambient $\mathrm{CO}_{2}$ concentration ratio $\left(C_{\mathrm{i}} / C_{\mathrm{a}}\right)$, and blast severity (Sev) determined in the leaves of rice plants grown in hydroponic culture containing $0 \mathrm{mM}(-\mathrm{Si})$ or $2 \mathrm{mM}(+\mathrm{Si})$ silicon $^{\mathrm{a}}$

\begin{tabular}{lccccc}
\hline Variables & $\mathrm{A}$ & $g_{\mathrm{s}}$ & $E$ & $C_{\mathrm{i}} / C_{\mathrm{a}}$ & $\mathrm{Sev}$ \\
\hline$A$ & $\ldots$ & $0.16^{\mathrm{ns}}$ & $0.74^{*}$ & $-0.55^{*}$ & $-0.59^{*}$ \\
$g_{\mathrm{s}}$ & $0.76^{*}$ & $\ldots$ & $0.55^{*}$ & $0.58^{*}$ & $0.29^{\mathrm{ns}}$ \\
$E$ & $0.81^{*}$ & $0.88^{*}$ & $\ldots$ & $-0.14^{*}$ & $-0.17^{\mathrm{ns}}$ \\
$C_{\mathrm{i}} / C_{\mathrm{a}}$ & $-0.20^{\mathrm{ns}}$ & $0.41^{*}$ & $0.17^{\mathrm{ns}}$ & $\ldots$ & $0.68^{*}$ \\
Sev & $-0.35^{\mathrm{ns}}$ & $-0.47^{*}$ & $-0.38^{*}$ & $-0.24^{\mathrm{ns}}$ & $\ldots$ \\
\hline
\end{tabular}

a Values above and below the diagonal are the measurements made at 08:00 and $12: 00 \mathrm{~h}$, respectively; $*=$ significant at $1 \%$ of probability according to the Student's $t$ test and ns $=$ not significant. the advanced stages of fungal infection, which can be attributed to the lytic enzymes and nonhost selective toxins produced by $P$. oryzae in the rice leaf tissue that can disrupt the electron transport chain in the thylakoid membranes (Chen et al. 2007, 2008). The observed values of ETR are more than sufficient for supporting the photochemical requirements of the actual $A$ values (Baker 2008; Lichtenthaler and Miehé 1997). Therefore, the decreases in the $A$ upon fungal infection could not be related to photochemical dysfunctions. It can be hypothesized that these dysfunctions might contribute to blast development by potentiating the occurrence of oxidative stress.

Due to the chronic overexcitation state on the leaves of -Si plants during the time course of $P$. oryzae infection, it can be hypothesized that these plants were subjected to an oxidative stress condition because the excess reducing power could not be fully dissipated. This hypothesis was supported by the higher $\mathrm{H}_{2} \mathrm{O}_{2}$ and MDA concentrations which reflect lipid peroxidation and the greater LOX activity for the $-\mathrm{Si}$ plants. The increased LOX activity with the progression of blast severity could be linked to the MDA production. Notably, the $+\mathrm{Si}$ plants generally accumulated $\mathrm{H}_{2} \mathrm{O}_{2}$ at the intermediate stages of fungal infection, which could be important for triggering some unknown mechanism of rice resistance to blast. In contrast to the results obtained from this study, the concentrations of $\mathrm{H}_{2} \mathrm{O}_{2}$ and MDA were maintained on the leaves of rice plants supplied with $\mathrm{Si}$ and infected by $P$. oryzae in a study by Sun et al. (2010). It was speculated that the high $\mathrm{H}_{2} \mathrm{O}_{2}$ concentrations for the $+\mathrm{Si}$ plants infected with $P$. oryzae can be readily controlled by the CAT activity because its activity was enhanced for the $+\mathrm{Si}$ plants at 84 hai, immediately after the peak $\mathrm{H}_{2} \mathrm{O}_{2}$ concentration. Therefore, it is plausible that the + Si plants could not only accumulate $\mathrm{H}_{2} \mathrm{O}_{2}$ but also temporally regulate its concentration through changes in the CAT activity. In the $-\mathrm{Si}$ plants, greater $\mathrm{H}_{2} \mathrm{O}_{2}$ concentrations upon $P$. oryzae infection could result in increases in the SOD activities, which catalyze the dismutation of $\mathrm{O}_{2}^{-}$to $\mathrm{H}_{2} \mathrm{O}_{2}$ when coupled with higher LOX activities that were not compensated for by increases in the concentrations of enzyme associated with $\mathrm{H}_{2} \mathrm{O}_{2}$ removal, such as CAT and APX. Indeed, the activities of these enzymes varied at different time periods. during $P$. oryzae infection and were accompanied only by inconsistent alterations in the GR activity. At 132 hai, no significant variations in the SOD, CAT, APX, and GR activities were observed in the presence of Si despite the enhanced excitation pressure (lower $q_{\mathrm{P}}$ coupled with lower NPQ) for these plants. This result implies that these plants were unable to induce further antioxidant defenses for coping with overexcitation, which ultimately helped to exacerbate the occurrence of oxidative stress and blast severity.

Overall, adequate $g_{\mathrm{s}}$ and $A$ values were maintained in the leaves of the rice plants supplied with $\mathrm{Si}$. The supply of Si helped protect the photosynthetic apparatus against chronic photoinhibition during $P$. oryzae infection and indirectly protected the photosystems against damage, which often results from a state of chronic hyperexcitation. Therefore, the rice plants supplied with $\mathrm{Si}$ and infected with $P$. oryzae are less prone to this chronic state of hyperexcitation than in the absence of Si. Moreover, the results of the present study show that the oxidative stress in rice plants infected by $P$. oryzae was alleviated in the presence of Si due to regulations in the activities of the enzymes involved in ROS scavenging, mainly the SOD, CAT, and APX.

\section{ACKNOWLEDGMENTS}

This study is part of a Ph.D. thesis presented by G. P. Domiciano at the Department of Plant Pathology, Universidade Federal de Viçosa. G. P. Domiciano was supported by CAPES. F. A. Rodrigues and F. M. DaMatta thank the National Council for Technological and Scientific Development (CNPq) for their fellowships. We thank A. A. Fortunato, A. J. Macabeu, and J. B. Ferreira for their technical assistance. This study was supported by grants from CAPES, CNPq, and FAPEMIG to F. A. Rodrigues. 


\section{LITERATURE CITED}

Alves, A. A., Guimarães, L. M. S., Chaves, A. R. M., DaMatta, F. M., and Alfenas, A. C. 2011. Leaf gas exchange and chlorophyll $a$ fluorescence of Eucalyptus urophylla in response to Puccinia psidii infection. Acta Physiol. Plant. 33:1831-1839.

Apel, K., and Hirt, H. 2004. Reactive oxygen species: Metabolism, oxidative stress, and signal transduction. Annu. Rev. Plant Biol. 55:373-399.

Aucique Perez, C. E., Rodrigues, F. A., Moreira, W. R., and DaMatta, F. M. 2014. Leaf gas exchange and chlorophyll $a$ fluorescence in wheat plants supplied with silicon and infected with Pyricularia oryzae. Phytopathology 104:143-149.

Aver'yanov, A. A., Lapikova, V. P., and Lebrun, M. H. 2007. Tenuazonic acid, toxin of rice blast fungus, induces disease resistance and reactive oxygen production in plants. Russ. J. Plant Physiol. 54:749-754

Axelrod, B., Cheesbrough, T. M., and Laasko, S. 1981. Lipoxygenases from soybeans. Methods Enzymol. 71:441-451.

Baker, N. R. 2008. Chlorophyll fluorescence: A problem of photosynthesis in vivo. Annu. Rev. Plant Biol. 59:89-113.

Balachandran, S., and Osmond, C. B. 1994. Susceptibility of tobacco leaves to photoinhibition following infection with two strains of tobacco mosaic virus under different light and nitrogen nutrition regimes. Plant Physiol. 3: 1051-1057.

Bastiaans, L. 1991. Ratio between virtual and visual lesion size as a measure to describe reduction in leaf photosynthesis of rice due to leaf blast. Phytopathology 81:611-615.

Bastiaans, L., and Roumen, E. C. 1993. Effect on leaf photosynthetic rate by leaf blast for rice cultivars with different types and levels of resistance. Euphytica 66:81-87.

Berger, S., Sinha, A. K., and Roitsch, T. 2007. Plant physiology meets phytopathology: Plant primary metabolism and plant-pathogen interactions. J. Exp. Bot. 58:4019-4026.

Bonman, J. M. 1992. Blast. Pages 14-16 in: Compendium of Rice Diseases. R. K. Webster and P. S. Gunnel, eds. The American Phytopathological Society, St. Paul, MN.

Bradford, M. N. 1976. A rapid and sensitive method for the quantitation of microgram quantities of protein utilizing the principle of protein-dye binding. Anal. Biochem. 72:248-254.

Brunings, A. M., Datnoff, L. E., Ma, J. F., Mitani, N., Nagamura, Y., Rathinasabapathi, B., and Kirst, M. 2009. Differential gene expression of rice in response to silicon and rice blast fungus Magnaporthe oryzae. Ann. Appl. Biol. 155:161-170.

Cakmak, L., and Horst, W. J. 1991. Effect of aluminum on lipid peroxidation, superoxide dismutase, catalase, and peroxide activity in root tip of soybean (Glycine max). Plant Physiol. 83:463-468.

Chen, S., Xu, X., Dai, X., Yang, C., and Qiang, S. 2007. Identification of tenuazonic acid as a novel type of natural photosystem II inhibitor binding in Q(B)-site of Chlamydomonas reinhardtii. Biochim. Biophys. Acta 1767: 306-318

Chen, S. G., Yin, C. Y., Dai, X. B., Qiang, S., and Xu, X. M. 2008. Action of tenuazonic acid, a natural phytotoxin, on photosystem II of spinach. Environ. Exp. Bot. 62:279-289.

Chou, H., Bundock, N., Rolfe, S. A., and Scholes, J. D. 2000. Infection of Arabidopsis thaliana leaves with Albugo candida (white blister rust) causes a reprogramming of host metabolism. Mol. Plant Pathol. 1: 99-113.

Datnoff, L. E., Rodrigues, F. A., and Seebold, K. W. 2007. Silicon and plant disease. Pages 233-246 in: Mineral Nutrition and Plant Disease. L. E. Datnoff, W. H. Elmer, and D. M. Huber, eds. The American Phytopathological Society, St. Paul, MN.

Debona, D., Rodrigues, F. A., Rios, J. A., Martins, S. C. V., Pereira, L. F., and DaMatta, F. M. 2014. Limitations to photosynthesis in leaves of wheat plants infected by Pyricularia oryzae. Phytopathology 104:34-39.

Detmann, K. C., Araújo, W. L., Martins, S. C. V., Sanglard, L. M. V. P., Reis, J. V., Detmann, E., Rodrigues, F. A., Nunes-Nesi, A., Fernie, A. R., and DaMatta, F. M. 2012. Silicon nutrition increases grain yield, which, in turn, exerts a feed-forward stimulation of photosynthetic rates via enhanced mesophyll conductance and alters primary metabolism in rice. New Phytol. 196:752-762.

Domiciano, G. P., Rodrigues, F. A., Vale, F. X. R., Xavier, M. S., Moreira, W. R., Andrade, C. C. L., and Pereira, S. C. 2010. Wheat resistance to spot blotch potentiated by silicon. J. Phytopathol. 158:334-343.

Epstein, E. 2009. Silicon: Its manifold roles in plants. Ann. Appl. Biol. 155: $155-160$.

Fauteux, F., Remus-Borel, W., Menzies, J. G., and Bélanger, R. R. 2005. Silicon and plant disease resistance against pathogenic fungi. FEMS Microbiol. Lett. 249:1-6.

Gao, D., Cai, K. Z., Chen, J. N., Luo, S. M., Zeng, R. S., Yang, J. Y., and Zhu, X. Y. 2011. Silicon enhances photochemical efficiency and adjusts mineral nutrient absorption in Magnaporthe oryzae infected rice plants. Acta Physiol. Plant. 33:675-682

Gay, C., and Gebicki, J. M. A. 2000. Critical evaluation of the effect of sorbitol on the ferricxylenol orange hydroperoxide assay. Anal. Biochem. 284: 217-220.

Giannopolitis, C. N., and Ries, S. K. 1977. Superoxide dismutases. I. Occurrence in higher plants. Plant Physiol. 59:309-314.

Havir, E. A., and McHale, N. A. 1989. Enhanced-peroxidatic activity in specific catalase isozymes of tobacco, barley, and maize. Plant Physiol. 91: $812-815$

Hoagland, D. R., and Arnon, D. I. 1950. The water-culture method for growing plants without soil. Calif. Agric. Exp. Stn. Circ. 347:1-32.

International Rice Research Institute. 1996. Standard Evaluation System for Rice. International Rice Research Institute, Manila, The Philippines.

Kim, S. G., Kim, K. W., Park, E. W., and Choi, D. 2002. Silicon-induced cell wall fortification of rice leaves: A possible cellular mechanism of enhanced host resistance to blast. Phytopathology 92:1095-1103.

Korndörfer, G. H., Pereira, H. S., and Nola, A. 2004. Análise de silício: Solo, planta e fertilizante.Boletim Técnico 1, Grupo de Pesquisa em Silício, ICIAG-Universidade Federal de Uberlândia, Uberlândia, Brazil.

Krause, G. H., and Weis, E. 1991. Chlorophyll fluorescence and photosynthesis: The basics. Annu. Rev. Plant Physiol. Plant Mol. Biol. 42:313-349.

Kuo, M. C., and Kao, C. H. 2003. Aluminum effects on lipid peroxidation and antioxidative enzyme activities in rice leaves. Biol. Plant. 46:149-152.

Liang, Y. C., Sun, W. C., Zhu, Y. G., and Christie, P. 2007. Mechanisms of silicon-mediated alleviation of abiotic stresses in higher plants: A review. Environ. Pollut. 147:422-428.

Lichtenthaler, H. K. 1987. Chlorophylls and carotenoids-Pigments of photosynthetic biomembranes. Methods Enzymol. 148:350-382.

Lichtenthaler, H. K., and Miehé, J. A. 1997. Fluorescence imaging as a diagnostic tool for plant stress. Trends Plant Sci. 2:316-320.

Lima, A. L. S., DaMatta, F. M., Pinheiro, H. A., Totola, M. R., and Loureiro, M. E. 2002. Photochemical responses and oxidative stress in two clones of Coffea canephora under water deficit conditions. Environ. Exp. Bot. 47: 239-247.

Logan, B. A., Adams, W. W., and Demming-Adams, B. 2007. Avoiding common pitfalls of chlorophylls fluorescence analysis under field conditions. Funct. Plant Biol. 34:853-859.

Ma, J. F., and Yamaji, N. 2006. Silicon uptake and accumulation in higher plants. Trends Plant Sci. 11:392-397.

Ma, J. F., Miyake, Y., and Takahashi, E. 2001. Silicon as a beneficial element for crop plants. Pages 17-39 in: Silicon in Agriculture. L. E. Datnoff, G. H. Korndörfer, and G. H. Snyder, eds. Elsevier Science, The Netherlands.

Meyer, S., Saccardy-Adji, K., Rizza, F., and Genty, B. 2001. Inhibition of photosynthesis by Colletotrichum lindemuthianum in bean leaves determined by chlorophyll fluorescence imaging. Plant Cell Environ. 24: 947-955.

Mittler, R. 2002. Oxidative stress, antioxidants and stress tolerance. Trends Plant Sci. 7:405-410.

Mohaghegh, P., Khoshgoftarmanesh, A. H., Shirvani, M., Sharifnabi, B., and Nili, N. 2011. Effect of silicon nutrition on oxidative stress induced by Phytophthora melonis infection in cucumber. Plant Dis. 95:455-460.

Moller, I. M. 2001. Plant mitochondria and oxidative stress: Electron transport, NADPH turnover, and metabolism of reactive oxygen species. Annu. Rev. Plant Physiol. Plant Mol. Biol. 52:561-591.

Nakano, Y., and Asada, K. 1981. Hydrogen peroxide is scavenged by ascorbate-specific peroxidase in spinach chloroplasts. Plant Cell Physiol. 22:867-880.

Ou, S. H. 1980. A look at worldwide rice blast disease control. Plant Dis. 64: 439-445.

Padhi, B., Chakrabarti, N. K., and Nayak, S. K. 1978. Effect of blast infection on photosynthetic activity of rice seedlings. Biol. Plant. 20:418-420.

Pinkard, E. A., and Mohammed, C. L. 2006. Photosynthesis of Eucalyptus globulus with Mycosphaerella leaf disease. New Phytol. 170:119-127.

Resende, R. S., Rodrigues, F. A., Cavatte, P. C., Martins, S. C. V., Moreira, W. R., Chaves, A. R. M., and DaMatta, F. M. 2012. Leaf gas exchange and oxidative stress in sorghum plants supplied with silicon and infected by Colletotrichum sublineolum. Phytopathology 102:892-898.

Rodrigues, F. A., Benhamou, N., Datnoff, L. E., Jones, J. B., and Bélanger, R. R. 2003. Ultrastructural and cytochemical aspects of silicon-mediated rice blast resistance. Phytopathology 93:535-546.

Rodrigues, F. A., Jurick, W. M., Datnoff, L. E., Jones, J. B., and Rollins, J. A. 2005. Silicon influences cytological and molecular events in compatible and incompatible rice-Magnaporthe grisea interactions. Physiol. Mol. Plant Pathol. 66:144-159.

Rodrigues, F. A., McNally, D. J., Datnoff, L. E., Jones, J. B., Labbé, C., and Benhamou, N. 2004. Silicon enhances the accumulation of diterpenoid phytoalexins in rice: A potential mechanism for blast resistance. Phytopathology 94:177-183. 
Seebold, K. W., Kucharek, T. A., Datnoff, L. E., Correa-Victoria, F. J., and Marchetti, M. A. 2001. The influence of silicon on components of resistance to blast in susceptible, partially resistant, and resistant cultivars of rice. Phytopathology 91:63-69.

Shaner, G., and Finney, R. E. 1977. The effect of nitrogen fertilization on the expression of slow-mildewing resistance in Knox wheat. Phytopathology 67:1051-1056.

Shetty, N. P., Mehrabi, R., Lütken, H., Haldrup, A., Kema, G. H., Collinge, D. B., and Jørgensen, H. J. 2007. Role of hydrogen peroxide during the interaction between the hemibiotrophic fungal pathogen Septoria tritici and wheat. New Phytol. 174:637-647.

Shtienberg, D. 1992. Effects of foliar disease on gas exchange process: A comparative study. Phytopathology 82:760-765.

Sun, W. C., Zhang, J., Fan, Q. H., Xue, G. F., Li, Z. J., and Liang, Y. C. 2010. Silicon-enhanced resistance to rice blast is attributed to silicon-mediated defence resistance and its role as physical barrier. Eur. J. Plant Pathol. 128: 39-49.

Swiech, R., Browning, S., Molsen, D., Stenger, D. C., and Holbrook, G. P. 2001. Photosynthetic responses of sugar beet and Nicotiana benthamiana Domin. infected with beet curly top virus. Physiol. Mol. Plant Pathol. 58:43-52.

Unger, C., Kleta, S., Jandl, G., and Tiedemann, A. v. 2005. Suppression of the defence-related oxidative burst in bean leaf tissue and bean suspension cells by the necrotrophic pathogen Botrytis cinerea. J. Phytopathol. 153:15-26.

Yoshida, S. S., Ohnishi, Y., and Kitagishi, K. 1962. Chemical forms, mobility, and deposition of silicon in rice plant. Soil Sci. Plant Nutr. 8:15-21.

Yoshii, H. 1937. Pathological studies of rice blast caused by Pyricularia oryzae. III Pathohistological observations of diseased plants. Ann. Phytopathol. Soc. Jpn. 6:289-304.

Yun, S.-C., Kim, P.-G., and Park, E. W. 2000. Alteration of gas exchange in rice leaves infected with Magnaporthe grisea. Plant Pathol. J. 16:279-285. 